\title{
Influence of Quality Management Practices on the Business Performance of Slovak Manufacturing Enterprises
}

\author{
Marek Potkány ${ }^{1}$, Pavol Gejdošํㅜ Petra Lesníková ${ }^{1}$, \\ Jarmila Schmidtová ${ }^{2}$
}

${ }^{1}$ Technical University in Zvolen, Department of Economics, Management and Business, T. G. Masaryka 24, 96001 Zvolen, Slovakia; potkany@tuzvo.sk, gejdosp@tuzvo.sk, lesnikova@tuzvo.sk

${ }^{2}$ Technical University in Zvolen, Department of Mathematics and Descriptive Geometry, T. G. Masaryka 24, 96001 Zvolen, Slovakia; schmidtova@tuzvo.sk

\begin{abstract}
The purpose of the paper is to point out the current state of using selected quality management practices in Slovak manufacturing enterprises. The research was focused on the application of selected practices of quality management, which can ensure that the customers' needs are met and thus contribute to the higher performance of the business. Selected practices of quality management - TQM, Kaizen, Six Sigma and Controlling of quality were considered such approaches. A specific aim of the paper is to find out the level of their real use and potential effects on business with relation to business's performance measured by the Return on Equity. The major research method was the primary quantitative research through a questionnaire. The survey data from 461 enterprises were analysed by the means of descriptive and inferential statistics. Since the variables of our interest are categorical in nature, we used appropriate nonparametric statistic technique Pearson's chi-square test. The 95\% confidence intervals for proportions were also calculated. The results indicate dependence between the business size, capital structure and use of quality management practices. At the same time, it can be concluded that businesses applying at least one of the quality management practices achieve higher performance measured by the ROE (above $7.5 \%$ ). Using the quality management practices, businesses can increase their economy and efficiency, reduce the unwanted variability in the processes and associated non-productive costs for increasing the production quality and customer satisfaction. Furthermore, these findings partially contribute to extension of knowledge in this research area.
\end{abstract}

Keywords: quality; quality management practices; performance; return on equity 


\section{Introduction}

The term of quality management is quite wide and complex. The first paradigm of quality management - product quality with aim of assuring a sufficient quality of products and avoiding of complaints from customers was extended the focus from product quality to process quality. The triangle of "Quality, Cost and Time" was applied not only on products but also on processes. It means that it is only possible to manufacture products at low costs and swiftly through capable and efficient processes [64]. Implementation of quality management practices in every type of enterprise requires managers and employees to adjust to new processes, methodologies and overall thinking. It is interesting that enterprises with a strong customer orientation are more able to implement the quality initiatives [61] [8] [41] [4].

In 2010, the EU along with the European Commission and Council of Europe created a successor to the Lisbon Strategy - the Europe 2020 Strategy containing of the transition to knowledge based economy and society and it means a challenge for most countries [12] [6]. Its main target is to provide support for inclusive and sustainable economic growth. Quality management is one of the factors that can contribute to these goals. The issues of quality, like production quality, management quality, and process quality, play an important role because constant quality improvement is one of the essential principles anchored in the ISO 9000 standard [24] as well as in the total quality management (TQM) philosophy. The TQM is seen as a quality operational enhancement model that is able to generate performance [23] [22].

Globalization and ever-rising customer demand forcing organizations and decision makers to come up with strategies to improve process and products continuously. To do that, they need a commitment from all stakeholders and the effective implementation of continuous improvement tools and techniques. From the point of quality management practices these three selected tools can be included: Six Sigma, Kaizen and Controlling of quality. Six Sigma shows a proven approach for businesses and organizations in how to improve their performance, through reducing variability in any process, reducing costs in manufacturing and services, and also, increasing customer satisfaction. According to Khan et al. [27] Kaizen is a Japanese terminology and means "change for the better." The Kaizen improvement focuses on the use of value-added and non-value-added work activities. Nowadays, according to Bieńkowska [7] controlling is understood as "a method of management support used mainly in the areas of planning and controlling - for the implementation of functions such as information supply, coordination, supervision, monitoring or participation in management; enabling managers - through its measurable and economical overtone - for making rational decisions, and thus aimed at achieving the goals of the organization as a whole and also at the area of quality." Through applying the principles of quality management, it is possible to achieve the sustainable development of a business, 
and ensure that the customers' requirements are met and thus promote the sustainable development of the whole society. Some of the benefits of using quality management practices are financial (savings, increasing revenue, etc.); qualitative (reduction of in-process defect levels, improving productivity); procedural (reduction of turnaround time, maintenance inspection time, etc.) [31]. From the study of Rahman, Shokshok, Wahab [48] it's evident that quality management practices have a positive effect mainly on improving product quality, improving the working environment, improving operational performance and improving customer satisfaction. The aim of this study is to review the current application of the selected quality management practices in the Slovak manufacturing enterprises that mostly rely on the enterprise size and their capital structure. Specific intention is to find out their real use, potential benefits and effects to the business performance measured by Return on Equity.

\section{Theoretical Background of Quality Management Practices}

Nowadays, almost every enterprise is trying to ensure sustainability. For partial achievement of this goal the use of quality management practices can be useful. It means that these practices can improve the quality of products, processes, and raw materials, and also reduce claims of customers, etc. That can ultimately have a positive impact on the running and sustainability of the business. To achieve sustainability in an enterprise it is necessary to focus not only on the results of the enterprise but also on its processes [21] [34]. The results of many studies [51] [40] indicate that the best management principles, models, and practices are those that positively contribute to sustainable development. Such principles also include quality management practices based on the use of the practices and methods such as TQM, Six Sigma, Kaizen, and Controlling of quality. Quality management and its future direction will be influenced by the changes and trends in an enterprise environment. A current trend is sustainable development that affects many areas of life. Global problems are part of solving the issue of sustainable development. These problems present great economic and social problems for everyone [3]. Quality management and sustainable development both have an emphasis on: stakeholders as customers and employees, their safety and satisfaction, their monitoring and self-evaluation for continuous improvement, waste reduction, employee engagement and training, and so on [28]. Except of the challenges of sustainable development, the requirements of Industry 4.0 are coming to the core of interest. In this context, research on quality managers' expectations related to the use of smart technologies is very actual [65].

Total quality management is one of the most significant management procedures of the $20^{\text {th }}$ Century. There have been numerous studies conducted in the field of 
TQM procedures and their impacts on businesses performance. Several studies [26] [39] have shown the relationship between total quality management practices and their effects on business performance. The implementation of TQM procedures is a way of increasing quality and reducing costs [11]. Mahmud and Hilmi [35] concluded that TQM is generally associated with the business process and management procedures. These procedures help to improve the efficiency and responsibility to meet the customers' needs through providing quality products and services. Total quality management contains several principles that are important in implementing it successfully. These principles include: understanding the customers' expectations, minimizing the costs for product modifications, supporting employee engagement, building reliable relationships with suppliers, and measuring the results and benchmarking that are used by most organizations [62]. Talib et al. [59] confirmed that the mentioned principles and their application certainly affect the evaluation of business performance.

The Six Sigma methodology (SSM) is an organized and systematic method of strategic processes based on the philosophy of statistics about a non-existent error rate of 3.4 defects per one million opportunities when considering the products and processes [32]. According to the research results [16] [25] the Six Sigma is a statistical indicator of the process capability, which is equivalent to $99.99966 \%$ of defect-free outputs. According to Töpfer [60] Six Sigma is project management with reliable statistical foundations and effective practices for quality management, it contains systematic methodology DMAIC (Define-MeasureAnalyse-Improve-Control) and DMADV (Define-Measure-Analyse-DesignVerify), process management, and a set of processes analysis practices to solve problems, statistics, philosophy, and quality culture at a zero-defect standard. Sujová et al. [58] stated that SSM is used as the process quality assurance and improvement method, as its implementation has achieved significant cost reduction, mainly in the machine, automotive, and electricity industry. Research studies [52] [14] [67] indicate that Six Sigma should be integrated in TQM to achieve synergistic effects for quality improvement. The impact of SSM on business performance is not questionable.

Kaizen is a creative and innovative operational strategy for increasing the competitiveness of businesses in the current turbulent environment [20] [38]. The key target of Kaizen is to build up a company's well-designed work culture to achieve continuous improvement of quality effectiveness and productivity. In addition, the Kaizen practices mainly focus on improvements without costs or only with low costs. In most scenarios, no costly equipment or sophisticated techniques are involved [1]. Kaizen procedures require all employees to participate in identifying the non-efficiency operations at all enterprise levels and subsequently take appropriate measures for continuous improvement [5]. Procedures of these quality management practices can help enterprises minimize the employee movements fluctuation of employees, costs, and errors, and improve the operators' skills, which will encourage employees to achieve the enterprise's 
key targets that in return can provide products and services with an economic value for their customers.

Control as a management tool is used in several business areas. According to Preißler [45] in theory there is no generally valid definition for the term of controlling, and therefore, one can encounter different opinions and definitions of this term. Quality controlling was created following the findings that quality, along with costs and delivery time, is considered one of the essential factors of success. Therefore, this concept using the economic aspect is used as a support for quality management [17]. Controlling of quality is one of the practices that can ensure, transform, and complete the information on economic results into a form suitable for management. The economic aspect of quality is becoming more important, and its aim is to make quality measurable, plannable, and manageable [54].

The production quality and its management have a great impact on businesses performance. Recent study has also confirmed that enterprises benefited from the incorporation of quality management practices [46]. The study of Nguyen et al. [40] investigate the relationship between quality management practices and sustainability performance as well as the moderating effects from a quality management implementation timeline, type of industry, and business size on this relationship. From the point of view of connecting the quality management practices with the economic performance this topic was discussed by several authors. Koc [29] in his study presented an alternative methodology to assess not only the direct impact of TQM on business performance, but the indirect impact on performance via internal and external failures. Within the economic performance following the quality management, it is recommended to focus on indicators such as financial return, financial expense, and market expansion. Samson and Terziovski [53] studied the relationship between the total quality management practices and operational performance of a large number of manufacturing enterprises individually and collectively. Many other studies [10] [43] support that quality management practices improve organizational performance in enterprises. Moreover, the implementation of organizational innovations demonstrable influence managerial work in different areas, at all levels of management [66].

In case of Slovakia, or Czech Republic some authors only partially (mainly in relation to TQM philosophy) payed attention to the effect of quality management practices on business performance [57] [44] [49]. Because there has been no similar research study in issue of effect selected quality management practices on manufacturing enterprises conducted either in Slovakia or abroad, the authors used their expertise in the branch characteristics, as well as the logic behind measuring the performance and quality management practices to formulate the working hypotheses (WH) and research question (RQ): 
Working hypothesis 1 (WH1): The authors suppose that enterprises use the selected quality management practices depending on the size of the enterprise.

Working hypothesis 2 (WH2): The authors suppose that enterprises with the prevailing part of the foreign capital structure apply the selected quality management practices to a greater extent than enterprises with prevailing domestic capital structure.

Working hypothesis 3 (WH3): Enterprises using the selected quality management practices achieve higher performance measured via the Return on Equity (ROE).

Research question 1 (RQ1): What particular changes or benefits do enterprises register by applying the quality management practices?

\section{Methodology}

The research methodology was comprised of three independent phases that followed one another. In the first phase, the methods of summary, synthesis, and analysis were used and a short review was prepared. In the second phase, a questionnaire was administered to generate empirical data from Slovak manufacturing enterprises. To evaluate the results of the research, the statistical program STATISTICA 12 was used. The third phase included the results in relation to business performance.

\subsection{Data Collection and Sample Size}

The subject of the research was manufacturing enterprises in the Slovak business environment. The object of the research was the application of the selected quality management practices such as TQM, Kaizen, SSM and Controlling of quality in these enterprises. These practices can ensure that the customers' needs are met and thus contribute to the higher performance of the business.

The primary data were collected through a questionnaire. Identification data of the enterprises included:

- The size of the enterprise based on the number of employees (small enterprises - up to 49 employees, medium-sized enterprises - up to 249 employees, and large enterprises - over 250 employees);

- Capital structure (prevailing ratio of the domestic or foreign capital);

- ROE: From a number of available methods, the ROE was selected for measuring the performance due to data availability. The level of ROE was divided into: negative value, value up to $7.5 \%$, and above $7.5 \%$. This index is available within the statistical databases of Slovak enterprises. 
The major research method was primary quantitative research using a questionnaire. The research was focused on the current state of quality management practices in the Slovak business environment. Proper guidelines and questionnaires with objectives of the study were distributed through e-mail, which were collected during January through March 2017. According to the Statistical Office of Slovak Republic [56] the population of our interest was contained of 21,605 manufacturing enterprises.

The minimum sample size was determined according to Eq. 1 for estimating the population proportion [37],

$\mathrm{n}=(\mathrm{z} / \mathrm{e})^{\wedge} 2 \times \mathrm{p} \times(1-\mathrm{p})$

where $\mathrm{z}$ is the value associated with degree of selected confidence, e is the maximum allowable error, and $\mathrm{p}$ is the estimated proportion $(\mathrm{p}=0.50$ in the case of no logical estimate).

Under conditions of a 0.95 degree of confidence and the maximum allowable error of $5 \%$, the sample size of 385 was a sufficient minimum.

\subsection{Methods of the Research Evaluation}

The survey data were evaluated based on descriptive, graphical, and statistical analyses. Because the variables of the authors' interest were categorical in nature - nominal or ordinal level of measurement, the authors used appropriate nonparametric statistic techniques.

The Pearson's chi-square test is one of the most commonly used nonparametric tests concerned with categorical variables. In the authors' research hypotheses, it is important to know whether two such variables are statistically independent of one another or whether these variables are statistically dependent where the probability of the occurrence of one is affected by the occurrence of the other. The chi-square statistic provides a careful measure of such relation [30]. The data were cross-classified into a contingency table. We also constructed $95 \%$ confidence intervals for population proportions. The interval estimate states the range within which a population parameter of proportion probably lies. All appropriate calculations were performed using statistical software STATISTICA 12.

\section{Results and Discussion}

As we mentioned in relation to sample size in part 3.1 our research sample of 461 questionnaires exceeded the required minimum and was thus considered satisfactory. At first we evaluated the current state of application of quality management practices that are characterized the sample via descriptive statistics. 
The frequency distribution of the 461 enterprises according to selected variables of size, capital structure, ROE value, and application of quality management practices, are indicated in Table 1.

Table 1

Frequency distribution of investigated enterprises according selected criteria

\begin{tabular}{|l|l|c|}
\hline Evaluation criterion & Evaluation sub-criterion & $\begin{array}{l}\text { Relative } \\
\text { value }\end{array}$ \\
\hline \multirow{3}{*}{ Size of enterprise } & Small & $71.80 \%$ \\
\cline { 2 - 3 } & Medium-sized & $14.97 \%$ \\
\cline { 2 - 3 } Capital structure & Large & $13.23 \%$ \\
\hline \multirow{3}{*}{ ROE value } & Domestic & $86.98 \%$ \\
\cline { 2 - 3 } & Foreign & $13.02 \%$ \\
\hline \multirow{4}{*}{$\begin{array}{l}\text { Application of quality } \\
\text { management practices }\end{array}$} & Negative & $7.16 \%$ \\
\cline { 2 - 3 } & Value up to 7.5\% & $71.58 \%$ \\
\cline { 2 - 3 } & Value above 7.5\% & $21.26 \%$ \\
\cline { 2 - 3 } & Practices are not used & $70.07 \%$ \\
\hline
\end{tabular}

From the overall number of 461 enterprises in the sample the most represented were small enterprises $(71.80 \%)$, enterprises with domestic capital $(86.98 \%)$ and enterprises with ROE value up to $7.5 \%(71.58 \%)$. We assume that representation of enterprises has also caused less use of quality management practices (only $29.93 \%$ enterprises).

\subsection{Results of Testing Hypotheses}

The first step in data analysis was to classify the 461 units into two-way distribution tables. For the needs of hypothesis testing, the expected frequencies were determined. Subsequently, Pearson's chi-square was applied. The 0.05 level of significance was used in the testing of all statistical hypotheses.

The first WH anticipated the businesses to use selected quality management practices depending on the size of the business. The observed and expected frequencies and also the values of the test statistics, as well as the degrees of freedom and corresponding p-level for all variables are presented in Table 2.

The null hypothesis about no relationship between two categorical variables is rejected at the significance level $\mathrm{p}=0.05$. There is a statistically significant dependence $(p=0.000)$ between the size of the business and the use of practices, which met the authors' expectation as defined in WH1. 
Table 2

Size enterprise and use of practices: observed (expected) frequencies and results of chi-square test

\begin{tabular}{|l|l|r|r|r|}
\hline \multicolumn{2}{|l|}{ Two-way distribution } & \multicolumn{2}{l|}{ Application of practices } & \multirow{2}{*}{ Total } \\
\cline { 3 - 5 } \multicolumn{2}{|l|}{} & Did not use & Used & \\
\hline \multirow{3}{*}{$\begin{array}{l}\text { Size of } \\
\text { enterprise }\end{array}$} & Small & $257(231.92)$ & $74(99.08)$ & 331 \\
\cline { 2 - 5 } & Medium-sized & $39(48.34)$ & $30(20.66)$ & 69 \\
\cline { 2 - 5 } & Large & $27(42.74)$ & $34(18.26)$ & 61 \\
\cline { 2 - 5 } & Total & 323 & 138 & 461 \\
\hline \multicolumn{2}{|l|}{ Pearson's chi-square $=34.461 ;$ degrees of freedom $=2 ;$ p-level $=0.000$} \\
\hline
\end{tabular}

Residual frequencies enabling a more detailed description of the specific dependence are presented in Fig. 1. The predominant feature (represented by residual frequencies) related to the use of quality management practices is marked in red. From this Figure it is evident that quality management practices are applied mainly in the large or medium-sized businesses. On the contrary, managing small businesses is characteristic by the use of quality practices was absent. These findings presented a logical outcome of the pragmatic aspect on the issue in question. A larger business had a higher need for overhead operations associated with production quality management and business management. This fact was supported by a high ratio of overhead costs in managing other supporting activities. These activities include marketing support, financial analyses and prognoses, research and development, and building a long-term image of the businesses.

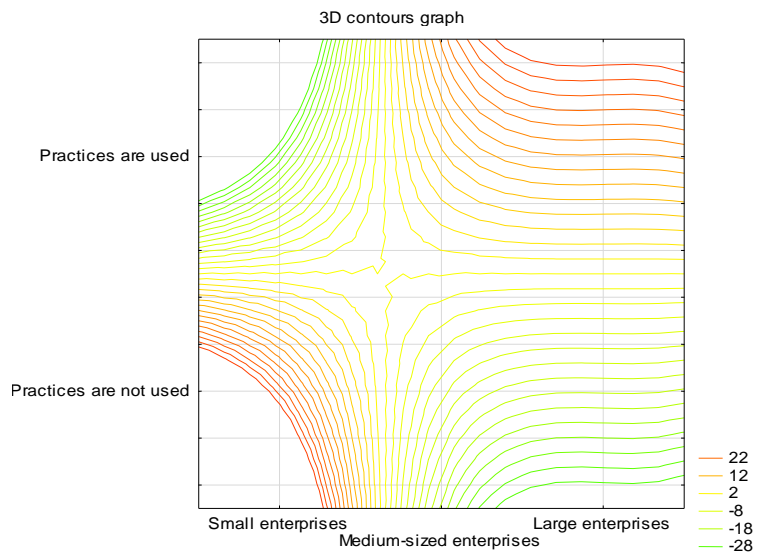

Figure 1

Size of enterprise and quality management practices - the residual frequencies

The WH2 studied the relationship between the share of foreign capital structure of the business ownership and the use of selected quality management practices. The results of hypothesis testing are presented in Table 3. 
Table 3

Capital structure and use of practices: observed (expected) frequencies and results of chi-square test

\begin{tabular}{|l|l|r|r|r|}
\hline \multicolumn{2}{|l|}{ Two-way distribution } & \multicolumn{2}{|c|}{ Application of practices } & \multirow{2}{*}{ Total } \\
\cline { 3 - 5 } \multicolumn{2}{|l|}{} & Did not use & Used & \\
\hline \multirow{2}{*}{$\begin{array}{l}\text { Capital } \\
\text { structure }\end{array}$} & Domestic & $293(280.96)$ & $108(120.04)$ & 401 \\
\cline { 2 - 5 } & Foreign & $30(42.04)$ & $30(17.96)$ & 60 \\
\cline { 2 - 5 } & Total & 323 & 138 & 461 \\
\hline \multicolumn{2}{|l|}{ Pearson's chi-square $=13.241 ;$ degrees of freedom $=1 ;$ p-level $=0.000$} \\
\hline
\end{tabular}

Following the Pearson's test statistics and corresponding p-level, the null hypothesis about independence was rejected $(\mathrm{p}=0.000)$. There was a significant dependence between the capital structure and the application of practices, which confirmed the authors' expectation from $\mathrm{WH} 2$.

Businesses with a prevailing share of foreign capital structure tended to use the quality management practices; whereas the businesses with a prevailing share of domestic capital structure did not use the quality management practices. This statement is based on the results in Figure 2, in which is indicated the dominant feature related to domestic and foreign capital structure of businesses and it is marked in red.

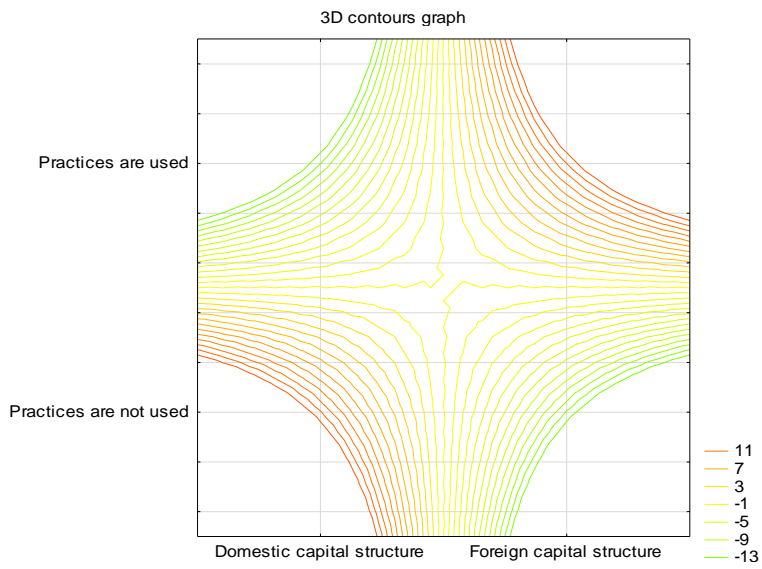

Figure 2

Capital structure of enterprise and quality management practices - the residual frequencies

It can be stated that these results were associated with a certain degree of constant increase in the share of foreign capital in Slovak enterprises, which brought the verified know-how in the sphere of management. Many businesses in the field of mechanical engineering, the electrotechnical and automotive industry, and a huge amount of trade companies have brought elements of precision, flexibility, and results orientation into management. As shown in Table 1, in the Slovak business environment one can find businesses with a prevailing share of domestic capital, 
which also use the selected practices of quality management. These practices were established in the business environment via benchmarking principles or through the natural development and requirements within the market approach.

The WH3 studied the relationship between the use of selected quality management practices and the performance measured via the level of ROE. The results of testing and also observed and expected frequencies are presented in Table 4.

Table 4

ROE value and use of practices: observed (expected) frequencies and results of chi-square test

\begin{tabular}{|c|c|c|c|c|}
\hline \multicolumn{2}{|c|}{ Two-way distribution } & \multicolumn{2}{|c|}{ Application of practices } & \multirow{3}{*}{$\begin{array}{r}\text { Total } \\
33 \\
\end{array}$} \\
\hline & & \multirow{2}{*}{$\begin{array}{r}\text { Did not use } \\
25(23.12)\end{array}$} & \multirow{2}{*}{$\begin{array}{l}\text { Used } \\
8(9.88)\end{array}$} & \\
\hline ROE value & Negative & & & \\
\hline & Value up to $7.5 \%$ & $242(231.21)$ & $88(98.79)$ & 330 \\
\hline & Value above $7.5 \%$ & $56(68.66)$ & $42(29.34)$ & 98 \\
\hline & Total & 323 & 138 & 461 \\
\hline
\end{tabular}

Pearson's chi-square $=9.993 ;$ degrees of freedom $=2 ;$-level $=0.007$

Statistically significant dependence $(\mathrm{p}=0.000)$ was also confirmed for the relationships between the ROE value and the quality management practices.

When studying the given dependence in more detail by using the residual frequencies (Fig. 3), it can be stated that the businesses applying quality management practices achieved higher performance measured by the ROE (above $7.5 \%$ ). This tendency is visible by red-highlighting. In contrast, businesses that did not use any of the analysed practices of quality management achieved a lower level of ROE (below 7.5\%), or the ROE value was negative.

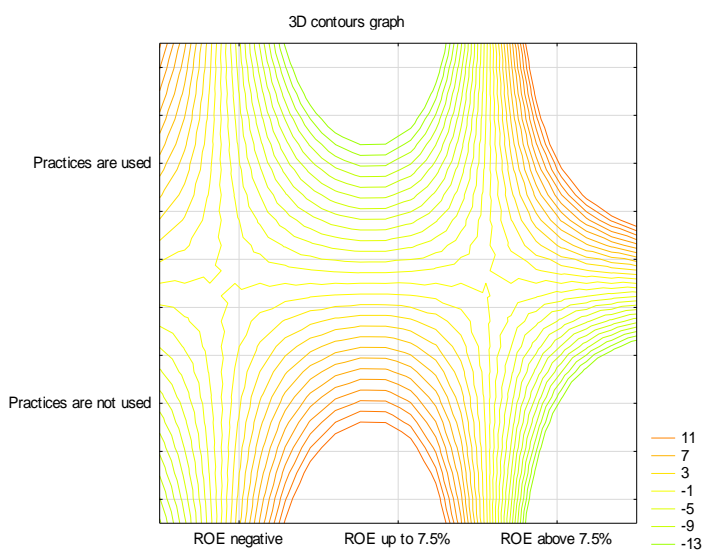

Figure 3

ROE value and quality management practices - the residual frequencies 
Based on the aforementioned claims, the authors confirmed WH3. The Slovak manufacturing enterprises that used the selected quality management practices achieved higher performance measured by ROE. When studying and evaluating the businesses' performance, several indicators were used. The most often used indicator was the ROE. The ROE has been used in many research studies for several years in connection with different areas: the effect of ROE on trading volume [19]; the effect of capital structure on profitability [2]. Rajnoha et al. [49] studied the ROE in connection with the business performance and the use of individual practices of strategic management. According to Finstat, the average value of ROE in the economic sectors in Slovakia for the year 2013 was 5.86\% [42]. In 2015, the ROE value was already at 7\% [15]. Therefore, the ROE value was anticipated to be $7.5 \%$ for the current average performance of enterprises in the Slovak business environment.

The practical use of the selected quality management practices definitely supports a higher production quality, as well as business management with an appreciable impact on its performance and building the competitive position. A common feature of a successful application of quality management principles is the constant effort to increase quality. Sujová et al. [58] stated that the use of TQM, Kaizen, and mainly Six Sigma can reduce unwanted process variability, which is a natural process component, nevertheless, its absolute uniformity cannot be achieved. The effect of the variability is that the efficiency of these processes is very low and not identical products are produced. Using the quality management practices (e.g., DMAIC model with the SSM) one can reduce the unwanted variability and the associated non-productive costs, thus improving the production quality and the customer satisfaction, which leads to an increase in the profit as suggested in research studies of various authors [18] [47] [50] [36] [55].

\subsection{Results of Research Question}

Through RQ1, we have focused our attention on the benefits of using quality management practices. The 95 percent confidence intervals presented in Table 5 indicate that the most common benefit is quality improvement, which is seen in the context of increasing the quality of products and their technical parameters, improving the quality of services provided, or supplying input materials. We estimate that this benefit has been recorded from 80 to 92 percent of manufacturing enterprises operating in Slovakia in 2017. From 30 to 47 percent of manufacturing enterprises consider an important benefit reducing customer complaints. Further results are given in Table 5. 
Table 5

The interval estimate for population proportion of enterprises which recorded individual benefits

\begin{tabular}{|l|r|r|r|r|}
\hline Individual benefits & $\begin{array}{c}\text { Quality } \\
\text { improvement }\end{array}$ & $\begin{array}{c}\text { Improvement } \\
\text { process } \\
\text { performance }\end{array}$ & $\begin{array}{c}\text { Lower costs } \\
\text { for non- } \\
\text { compliance } \\
\text { products }\end{array}$ & $\begin{array}{c}\text { Lower } \\
\text { number of } \\
\text { customer } \\
\text { complaints }\end{array}$ \\
\hline $\begin{array}{l}\text { Point estimate of } \\
\text { proportion }\end{array}$ & 0.8623 & 0.2971 & 0.1304 & 0.3841 \\
\hline $\begin{array}{l}\text { Interval estimate - } \\
\text { lower limit }\end{array}$ & 0.8048 & 0.2209 & 0.0742 & 0.3029 \\
\hline $\begin{array}{l}\text { Interval estimate - } \\
\text { upper limit }\end{array}$ & 0.9198 & 0.3733 & 0.1866 & 0.4652 \\
\hline
\end{tabular}

In relation to RQ1 our research has focused attention on the issue of quality cost monitoring in the conditions of Slovak manufacturing enterprises. From the sample $(n=461)$, the largest number of enterprises $(38.18 \%$; 176) monitors internal and external failure costs and appraisal (control) costs $(140 ; 30.37 \%)$. An interesting finding is that many businesses $(110 ; 23.86 \%)$ still do not monitor quality costs at all. To a lesser extent, the costs of prevention $(103 ; 22.34 \%)$ or the cost of lost investments and opportunities $(61 ; 13.23 \%)$ are monitored. Less than $10 \%$ of businesses monitor costs are related to environmental damage, noncompliance and compliance costs. From the point of view the size of enterprises, the results of the monitoring of the quality costs are presented in Fig. 4.

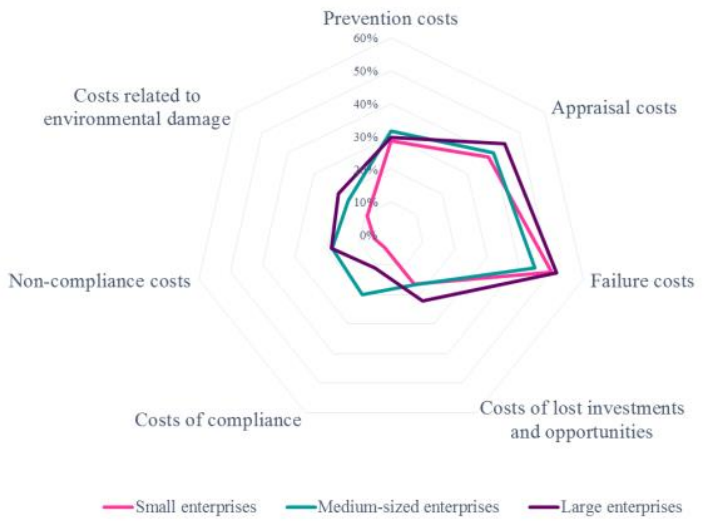

Figure 4

The quality of costs monitored by enterprises

The situation with regard to dependence of the enterprise size and monitoring of quality costs is similar. However, we can conclude that the largest proportion of enterprises monitoring the failure costs, appraisal costs and prevention costs is from the category of large enterprises. 


\section{Conclusions}

In conclusion it can be stated that quality management practices can positively influence the increasing of production quality and process performance, reducing the number of complaints with a secondary cost reduction for nonconforming products. Furthmore. our findings show the impact of using quality management practices on business performance. In this case, it was important to conclude that the business's performance also depended on other factors, besides those quality management practices analysed within this study. The significant impact on the business's performance can be quantified depending on the experience and knowledge of the human capital, applying the strategic practices of decisionmaking support, the degree of technologization supported by the information technologies, and production automation. The branch, its specifics and future trend in the research and development are also appreciable issues. Nevertheless, the field of measuring the performance, with the possibility of applying the procedures based on the evaluation and development of the level of Economic Value Added, Market Value Added, Shareholder Value Added, remains questionable. Several studies [9] [13] [33] [63] have been published on this specific topic. Nonetheless, it can be claimed with certainty that the field of quality management practices can significantly help to build, maintain, and improve the businesses' competitiveness and performance.

This study investigated the current state of using selected quality management practices in Slovak manufacturing enterprises in relation to the business size and capital structure. In accordance with WH1, the results revealed that quality management practices were applied as the business strategy mainly in large or medium-sized Slovak enterprises. With statistically significant dependence $(\mathrm{p}=$ 0.000 ) between the size of the business and the use of quality management practices, WH1 was accepted. From the capital structure perspective (WH2), the results showed that the increased use of the selected quality management practices in Slovak manufacturing enterprises depended on the capital structure. Most large and some medium-sized businesses with the prevailing share of foreign capital employed a combination of several analysed quality management practices. The decreasing share of foreign capital structure caused a decrease in the amount of surveyed practices. The results of the Pearson's test statistics and corresponding plevel confirmed WH2. Finally, enterprises that used the selected quality management practices achieved higher performance measured by the ROE (above $7.5 \%$ ) in which WH3 was also confirmed. This value can even increase when combined with the practical use of the analysed practices. In contrast, businesses that practically did not use any of the analysed practices, or they only minimally applied the practices, achieved significantly lower or negative values of ROE.

The limitations of the present research can be seen in the possibility of extending the analysed respondent sample with the specification to define the dependencies from the aspect of regional, branch, and organizational structure of the businesses. At the same time, the authors are aware of the possibility of using quantification 
of the business performance via other methods (Economic Value Added and Benchmarking, methods on principles Activity Based Management or Balanced Scorecard), as well as other quality management practices (EFQM model, Process and Lean management). This field is intended to be the focus of further research studies by the authors. These practices, in combination with the already analysed ones, can support achieving business results regarding the customers' requirements and quality of the competitors. They can add an economic aspect to more technically oriented quality management and contribute to the business strategy that encourages the business' sustainable development and increasing performance.

\section{Acknowledgement}

This research was funded by KEGA No. 005TU Z-4/2020 „Economics, Management and Enterprising in Wood Industry Companies - University Textbooks with the Support of Visualization in Virtual Space" and project APVV18-0520 Innovative methods for analyzing the performance of wood and forestry complex using the principles of green growth.

\section{References}

[1] H. Abdulmouti: The role of Kaizen (continuous improvement) in improving companies' performance: A case study. International Conference on Industrial Engineering and Operations Management, Dubai, United Arab Emirates, 2015, pp. 1-6

[2] J. Abor: The effect of capital structure on profitability: An empirical analysis of listed firms in Ghana. Journal of Risk Finance, 6(5), 2005, pp. 438-445

[3] P. Adamisin, R. Kotulic, L. Mura, I. Kravcakova Vozarova, and R. Vavrek: Managerial approaches of environmental projects: an empirical study. Polish Journal of Management Studies, 17(1), 2018, pp. 27-38

[4] C. Anyakoha: Job analysis as a tool for improved organizational performance of SMEs in Lagos, Nigeria. Central European Journal of Labour Law and Personnel Management, 2(1), 2019, pp. 7-16

[5] T. M. Aurel, A. Simina, and T. Stefan: Continuous quality improvement in modern organizations through Kaizen. $9^{\text {th }}$ Research/Expert Conference with International Participations QUALITY 2015, Neum, Bosna-Herzegovina, pp. 27-32

[6] A. Bencsik, T. Juhasz, L. Mura, and A. Csanadi: Impact of informal knowledge sharing for organizational operation. Entrepreneurial Business and Economics Review, 7(3), 2019, pp. 25-42

[7] A. Bieńkowska: Controlling - striving for excellence implementation of model solutions in organizations operating in Poland. International Journal of Industrial Engineering and Management, 10(1), 2019, pp. 31-40 
[8] S. Borkowski, and R. Stasiak-Betlejewska: The importance level of quality management elements in Polish construction company development strategy. Acta Oeconomica Universitatis Selye, 4(1), 2015, pp. 9-22

[9] A. Chakraborty, J. L. Grant, and E. A. Trahan: The EVA style approach to tactical asset allocation. Journal of Wealth Management, 20(2), 2017, pp. 41-53

[10] T. C. E. Cheng, and P. W. C. Choy: A study of the relationships between quality management practices and organizational performance in the shipping industry. Maritime Economics \& Logistics, 15(1), 2013, pp. 1-31

[11] A. D. Darshak: Cost of quality in small- and medium-sized enterprises: Case of an Indian engineering company. Production Planning \& Control, 19(1), 2008, pp. 25-34

[12] E. Dul'ová Spišáková, L. Mura, B. Gontkovičová, and Z. Hajduová: R\&D in the context of Europe 2020 in selected countries. Economic Computation and Economic Cybernetics Studies and Research, 51(4), 2017, pp. 243-261

[13] M. Ebel, J. Pilkington, J. Rowe, and S. Srinivasan: Value added from trade for key business and financial service industries: Initial estimates. National Institute Economic Review, 242(1), 2017, R14-R23

[14] J. Ferng, and A. D. F. Price: An exploration of the synergies between Six Sigma, total quality management, lean construction and sustainable construction. International Journal of Six Sigma and Competitive Advantage, 1(2), 2005, pp. 167-187

[15] Financial Report. Industry Analysis in the SR: Success in Industry 4.0 requires investment, 2017, Available at https://www.finreport.sk/agenturnespravy/analyza-priemyslu-v-sr-uspech-vo-vyzve-priemysel-4-0-vyzadujeinvesticie/. Accessed 20 May 2019

[16] E. V. Gijo, J. Scaria, and J. Antony: Application of six sigma methodology to reduce defects of a grinding process. Quality and Reliability Engineering International, 27(8), 2011, pp. 1221-1234

[17] W. Hansen, and G. F. Kamiske: Qualitäts Management [Quality Management], Digitale Fachbibliothek, Symposion Publishing GmbH, Düsseldorf, Germany, 2003

[18] M. Holíková: Possibilities of Quality Controlling in the Conditions of Wood and Furniture Industry, Technical University in Zvolen, Zvolen, SR, 2010

[19] S. Ichsani, and A. R. Suhardi: The effect of return on equity (ROE) and return on investment (ROI) on trading volume. Procedia - Social and Behavioral Sciences, Vol. 211, 2015, pp. 896-902

[20] M. Imai: Gemba Kaizen - Management and Quality Improvement in the Workplace, Computer Press, Brno, Czech Republic, 2005 
[21] M. Jasiulewicz-Kaczmarek: Is sustainable development an issue for quality management? Foundations of Management, 6(2), 2014, pp. 51-66

[22] T. Jayawardane, and C. De Alwis: Solving for the equilibrium in TQM aspects and constructing of its computation instrument. Acta Oeconomica Universitatis Selye, 6 (1), 2017, pp. 51-60

[23] D. Jimenéz-Jimenéz, M. Martinez-Costa, A. R. Martinez-Lorente, and H. A. D. Rabeh: Total quality management performance in multinational companies: A learning perspective. The TQM Journal, 27(3), 2015, pp. 328-340

[24] P. L. Johnson: ISO 9000: Meeting The International Standards. McGrawHill, New York, USA, 1997

[25] P. Kaushik, D. Khanduja, K. Mittal, and P. Jaglan: A case study: Application of Six Sigma methodology in a small and medium-sized manufacturing enterprise. The TQM Journal, 24(1), 2012, pp. 4-16

[26] H. Kaynak: The relationship between total quality management practices and their effects on firm performance. Journal of Operations Management, 21(4) 2003, pp. 405-435

[27] S. A. Khan, M. A. Kaviani, B. J. Galli, and P. Ishtiaq: Application of continuous improvement techniques to improve organization performance: A case study. International Journal of Lean Six Sigma, 10(2), 2019, pp. $542-565$

[28] L. M. Khodeir, and R. Othman: Examining the interaction between lean and sustainability principles in the management process of AEC industry. Ain Shams Engineering Journal, 9(4), 2016, pp. 1627-1634

[29] T. Koc: The relationship between TQM and performance in small manufacturing enterprises: The mediation effect of failure. The International Journal of Industrial Engineering, 18(4), 2011, pp. 203-218

[30] H. Kohler: Statistics for Business and Economics, Scott, Foresman and Company, Glenview, USA, 1988

[31] Y. H. Kwak, and F. T. Anbari: Benefits, obstacles, and future of six sigma approach. Technovation, 26(5-6), 2006, pp. 708-715

[32] K. Linderman, R. G. Schroeder, S. Zaheer, and A. S. Choo: Six Sigma: A goal-theoretic perspective. The Journal of Operations Management, 21(2), 2003, pp. 193-203

[33] Z. J. Liu, and Y. S. Wang: Effect of earnings management on economic value added: G20 and African countries study. South African Journal of Economic and Management Sciences, 20(1), 2017, pp. 1-9 
[34] S. Lorincová, M. Hitka, and Ž. Balážová: Corporate culture in Slovak enterprises as a factor of HRM quality - Case study. International Journal for Quality Research, 10(4), 2016, pp. 719-732

[35] N. Mahmud, and M. F. Hilmi: TQM and Malaysian SMEs performance: The mediating roles of organization learning. Procedia - Social and Behavioral Sciences, Vol. 130, 2014, pp. 216-225

[36] K. Marcineková, and A. Sujová: The influence of the process control level on the enterprises' ROE. Procedia Economics and Finance, Vol. 34, 2015, pp. 290-295

[37] R. D. Mason, and D. A. Lind: Statistical Techniques in Business and Economics, IRWIN, Boston, USA, 1990

[38] L. Mura, and Z. Rózsa: The impact of networking on the innovation performance of SMEs. $7^{\text {th }}$ International Days Of Statistics And Economics, 2013, pp. 1036-1042

[39] A. Nair: Meta-analysis of the relationship between quality management practices and firm performance-implications for quality management theory development. Journal of Operations Management, 24(6), 2006, pp. 948-975

[40] M. H. Nguyen, A. C. Phan, and Y. Matsui: Contribution of quality management practices to sustainability performance of Vietnamese firms. Sustainability, 10(2), 2018, pp. 375-405

[41] M. Nosková, and T. Peráček: Termination of employment in the Slovak Republic as a key issue of HR Management. Central European Journal of Labour Law and Personnel Management, 2(2), 2019, pp. 44-59

[42] M. Ondrušeková, and J. Pohorský: Return on equity and return on assets of Slovak companies by sector and region. Finance Manager, 15(1), 2015, pp. 21-27

[43] V. S. Patyal, and M. Koilakuntla: The impact of quality management practices on performance: an empirical study. Benchmarking: An International Journal, 24(2), 2017, pp. 511-535

[44] J. Pokorná, and P. Suchánek: The impact of strategic management tools on product quality and business performance. Proceedings Paper International Multidisciplinary Scientific Conferences on Social Sciences and Arts (SGEM 2014), pp. 327-334

[45] A. Preißler: Praxiswissen Controlling [Practical Knowledge Controlling], Carl Hanser Verlag GmbH \& Co., KG, München, Germany, 2010

[46] E. Psomas, F. Vouzas, and D. Kafetzopoulos: Quality management benefits through the "soft" and "hard" aspect of TQM in food companies. The TQM Journal, 26(5), 2014, pp. 431-444 
[47] T. Pyzdek, and P. Keller: The Six Sigma Handbook, McGraw-Hill, New York, USA, 2010

[48] M. N. A. Rahman, M. A. Shokshok, and D. A. Wahab: Barriers and benefits of total quality management implementation in Libyan manufacturing companies. Middle-East Journal of Scientific Research, 7(4), 2011, pp. 619-624

[49] R. Rajnoha, and M. Merková: Aim and methodology of research. In R. Rajnoha, J. Drábek, A. Sujová, M. Merková, L'. Simanová, and I. Volčko: Measurement and Management Business Performance, Technical University in Zvolen, Zvolen, SR, 2013

[50] M. K. Rastogi: Production and Operation Management, Laxmi Publications, New Delhi, India, 2010

[51] M. F. Rebelo, G. Santos, and R. Silva: Integration of management systems: Towards a sustained success and development of organizations. Journal of Cleaner Production, Vol. 127, 2016, pp. 96-111

[52] L. Revere, and K. Black: Integrating Six Sigma with total quality management: A case example for measuring medication errors. Journal of Healthcare Management, 48(6), 2003, pp. 377-391

[53] D. Samson, and M. Terziovski: The relationship between total quality management practices and operational performance. Journal of Operations Management, 17(4), 1999, pp. 393-409

[54] A. Sasse: Systematisierung der Qualitätskosten und der Abweichungskosten für das Qualitätskosten Management [Systematization of Quality Costs and Deviation Costs for Quality Cost Management], Zeitschrift Kostenrechnungspraxis Qualitätscontrolling, Germany, 2000

[55] L. Simanová: Specific proposal of the application and implementation Six Sigma in selected processes of the furniture. Procedia Economics and Finance, 34, 2015, pp. 268-275

[56] Statistical Office of Slovak republic (2018) Available at http://statdat.statistics.sk/cognosext/cgibin/cognos.cgi?b_action=xts.run\&m $=$ portal/cc.xts\&gohome=. Accessed 20 May 2019

[57] P. Suchánek, and A. Klapalová: Quality management and its impact on business performance. Proceedings Paper from International Scientific Conference on the Poprad Economic and Management Forum, 2017, pp. $100-110$

[58] A. Sujová, L. Simanová, and K. Marcineková: Sustainable process performance by application of Six Sigma concepts: The research study of two industrial cases. Sustainability, 8(3), 2016, pp. 260

[59] F. Talib, Z. Rahman and M. N. Qureshi: An empirical investigation of relationship between total quality management practices and quality 
performance in Indian service companies. International Journal of Quality \& Reliability Management, 30(3), 2013, pp. 280-318

[60] A. Töpfer: Six Sigma, Computer Press, Praha, Czech Republic, 2008

[61] M. Uluskan, J. K. McCreery, and L. Rothenberg: Impact of quality management practices on change readiness due to new quality implementations. International Journal of Lean Six Sigma, 9(3), 2018, pp. 351-373

[62] C. Valmohammadi, and S. Roshanzamir: The guidelines of improvement: Relations among organizational culture, TQM and performance. International Journal of Production Economics, 164, 2015, pp. 167-178

[63] M. Venugopal, B. Prakash, and R. Reddy: Impact of capital structure on shareholder value in Indian pharmaceutical industry: An empirical approach through created shareholder value. Global Business Review, 19(5), 2018, pp. 1290-1302

[64] A. Weckenmann, G. Akkasoglu, and T. Werner: Quality management history and trends. The TQM Journal, 27(3), 2015, pp. 281-293

[65] Z. Závadská, and J. Závadský: Quality managers and their future technological expectations related to Industry 4.0. Total Quality Management \& Business Excellence, 31(7-8), 2018, pp. 717-741

[66] J. Závadský, M. Kožárová, M. Vinczeová, Z. Tučková, and J. Krivosudská: How organizational innovations help managers to improve quality of their work: An empirical study. International Journal of Quality Research, 12(4), 2018, pp. 905-924

[67] X. Zu, L. D. Fredendall, and T. J. Douglas: The evolving theory of quality management: The role of Six Sigma. Journal of Operations Management, 26(5), 2008, pp. 630-650 